\title{
Antifungal Activity of Coumarin Mammeisin Isolated from Species of the Kielmeyera Genre (Family: Clusiaceae or Guttiferae)
}

\author{
Helcio Cassemiro Marcondes, ${ }^{1}$ Tânia T. de Oliveira, ${ }^{2}$ Jason G. Taylor, ${ }^{1}$ Moisés Hamoy, \\ Arman do Leonel Neto, ${ }^{1}$ Vanessa Joia de Mello, ${ }^{3}$ and Tanus J. Nagem ${ }^{1}$ \\ ${ }^{1}$ Chemistry Department, Federal University of Ouro Preto, Morro do Cruzeiro, \\ 34500-000 Ouro Preto, MG, Brazil \\ ${ }^{2}$ Department of Biochemistry, Federal University of Viçosa, 36570-900 Viçosa, MG, Brazil \\ ${ }^{3}$ Institute of Biological Sciences, Federal University of Pará, 66075-110 Belém, PA, Brazil
}

Correspondence should be addressed to Helcio Cassemiro Marcondes; helciocassemiro@yahoo.com.br

Received 24 July 2014; Revised 3 November 2014; Accepted 28 January 2015

Academic Editor: Kamel H. Shaker

Copyright (c) 2015 Helcio Cassemiro Marcondes et al. This is an open access article distributed under the Creative Commons Attribution License, which permits unrestricted use, distribution, and reproduction in any medium, provided the original work is properly cited.

\begin{abstract}
Coumarin mammeisin isolated from Kielmeyera elata was evaluated for its toxicity and antifungal activities. The toxicity of mammeisin was investigated by utilizing the Artemia salina methodology to determine its $\mathrm{LD}_{50}$ value. The minimum inhibitory concentration (MIC) of fungi Candida sp. was assessed for mammeisin, presenting equivalent activity to ketoconazole but displaying better results than fluconazole.
\end{abstract}

\section{Introduction}

The current pharmacotherapy used against human fungal diseases is based on azole compounds. Unfortunately, the emergence of microorganisms resistant to azole antifungals is increasing in number and patients at risk of acquiring fungal infections have created new challenges. The demand for drugs of plant origin has led to a renewed interest in pharmaceutical coumarins, chromones, and xanthones, given the fact that these substances show potent pharmacological activities and low toxicity to mammals [1].

Amongst the many pharmacological functions of coumarins a few stand out, such as scoparone (6,7-dimethoxycoumarin), isolated from the Chinese plant Artemisia scoparia Waldst. Osthole coumarin (a C-prenylated coumarin) inhibited platelet aggregation and was able to induce relaxation of the smooth muscles of the heart, possibly due to inhibition of the enzyme cAMP- and cGMP-phosphodiesterase and calcium influx [2]. Coumarins such as calanolides A and
B (pyranocoumarins) exhibited anti-HIV activity by impeding the in vitro replication of HIV-1, probably by inhibiting the enzymatic activity of DNA polymerase-dependent DNA and DNA-dependent RNA polymerase present in viruses [3].

The genus Kielmeyera belongs to the family Clusiaceae (Guttiferae), part of the subfamily Kielmeyeroidae, which is endemic in South America, and most species are exclusively native of the Brazilian flora. Coumarins isolated from Kielmeyera elata, which are pertinent to this report, include mammeisin (Figure 1). Mammeisin can essentially be classified as a C-prenylated coumarin and was isolated from the stem of Kielmeyera elata by our group [4]. Mammeisin has also been more recently identified in Mammea americana L. seeds and has been evaluated for its cytotoxic and antioxidant properties [5].

Until now, its antifungal activities had not been investigated; thus, we isolated the natural product from the stem of Kielmeyera elata in order to evaluate its potential antifungal properties. 


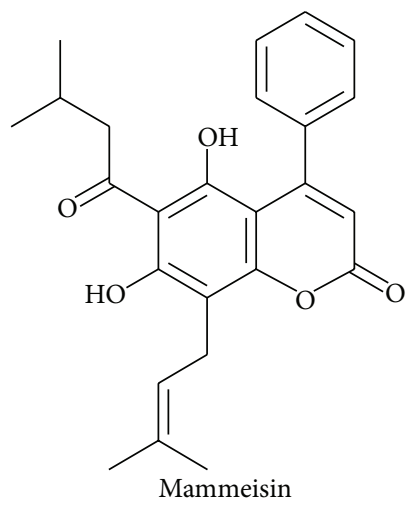

Figure 1: Chemical structure of mammeisin.

\section{Experimental}

2.1. Isolation and Characterization of Natural Product Mammeisin. Mammeisin was isolated from the stems of Kielmeyera elata as described by our group [4] and its structure confirmed by spectroscopic analysis. Pale yellow prisms, mp $102-104^{\circ} \mathrm{C} ; \delta_{\mathrm{H}}\left(300 \mathrm{MHz}, \mathrm{CDCl}_{3}\right): 0.89(6 \mathrm{H}, \mathrm{d}, J$ 6.9), 1.76 (3H, s), 1.89 (3H, s), 2.19 (1H, sept, J 6.6), 2.85 (2H, d, J 6.9), $3.57(2 \mathrm{H}, \mathrm{d}, J \mathrm{~J} .2), 5.26(1 \mathrm{H}, \mathrm{t}, J$ 7.2) $, 5.96(1 \mathrm{H}, \mathrm{s}), 7.39-7.41(2 \mathrm{H}$, $\mathrm{m}), 7.52-7.54(3 \mathrm{H}, \mathrm{m}), 9.93(1 \mathrm{H}, \mathrm{s}), 11.04(1 \mathrm{H}, \mathrm{s}) ; \delta_{\mathrm{C}}(75 \mathrm{MHz}$, $\mathrm{CDCl}_{3}$ ): 207.4, 163.5, 159.8, 159.5, 156.9, 154.7, 137.5, 135.7, 130.0, $129.4,127.7,120.9,112.9,108.2$, 107.5, 101.1, 53.9, 29.9, 26.1, 24.9, $22.9,21.9,18.2,14.4$.

\subsection{Evaluation of Biological Activities}

2.2.1. Antifungal Activity. The evaluation used the antifungal method for determination of minimum inhibitory concentration (MIC), according to the broth microdilution technique recommended by the CLSI document M27-A2. The methodology employed for testing antifungal activity was divided into four stages: preparation of the dilutions from all compounds tested, preparation of dilutions of the antifungal agents (in this case, ketoconazole and fluconazole), preparation of inocula with species of Candida (C. albicans, C. tropicalis, C. parapsilosis, C. krusei), and finally plating. The dilutions for all compounds tested consisted of solubilizing, $12.0 \mathrm{mg}$ in $6.0 \mathrm{~mL}$ of DMSO, resulting in a solution with $2000 \mu \mathrm{g} / \mathrm{mL}$ and then dilutions were made successively with the culture medium RPMI (Roswell Park Memorial Institute) to yield ten concentrations 512.0, 256.0, 128.0, 64.0, 32.0, 16.0, 8.0, 4.0, 2.0, and $1.0 \mu \mathrm{g} / \mathrm{mL}$ (extract + RPMI + DMSO). As for the antifungal compounds fluconazole and ketoconazole, $5.0 \mathrm{mg}$ was diluted in $5.0 \mathrm{~mL}$ DMSO resulting in two solutions with a concentration of $1000 \mu \mathrm{g} / \mathrm{mL}$; then the solutions were diluted with culture medium (RPMI) to give dilutions of fluconazole $64.0 \mu \mathrm{g} / \mathrm{mL}, 32.0 \mu \mathrm{g} / \mathrm{mL}, 16.0 \mu \mathrm{g} / \mathrm{mL}, 8.0 \mu \mathrm{g} / \mathrm{mL}$, $4.0 \mu \mathrm{g} / \mathrm{mL}, 2.0 \mu \mathrm{g} / \mathrm{mL}, 1.0 \mu \mathrm{g} / \mathrm{mL}, 0.5 \mu \mathrm{g} / \mathrm{mL}, 0.25 \mu \mathrm{g} / \mathrm{mL}$, and $0.125 \mu \mathrm{g} / \mathrm{mL}$ and for ketoconazole $32.0 \mu \mathrm{g} / \mathrm{mL}, 16.0 \mu \mathrm{g} / \mathrm{mL}$, $8.0 \mu \mathrm{g} / \mathrm{mL}, \quad 4.0 \mu \mathrm{g} / \mathrm{mL}, \quad 2.0 \mu \mathrm{g} / \mathrm{mL}, \quad 1.0 \mu \mathrm{g} / \mathrm{mL}, \quad 0.5 \mu \mathrm{g} / \mathrm{mL}$, $0.25 \mu \mathrm{g} / \mathrm{mL}, 0.125 \mu \mathrm{g} / \mathrm{mL}$, and $0.0625 \mu \mathrm{g} / \mathrm{mL}$.

The plates were incubated at $28^{\circ} \mathrm{C}$ and readings were taken after 48 hours to analyse the fungal growth at different courmarin concentrations against a positive control. MICs were obtained by visual reading and expressed in $\mu \mathrm{g} / \mathrm{mL}$.

2.2.2. Toxicity Evaluation: Artemia salina. In order to obtain Artemia salina, the microcrustacean eggs were placed in an aquarium with saline solution (sea salt of artificial Red Sea) and allowed to hatch at a concentration of $38.0 \mathrm{~g} / \mathrm{L}$ under oxygenation and light radiation for $48 \mathrm{~h}$. Next, $40.0 \mathrm{mg}$ of dry extract was diluted in $4.0 \mathrm{~mL}$ of DMSO and from this solution aliquots of $5,50,250$, and $500 \mu \mathrm{L}$ were withdrawn, which were then transferred to test tubes to allow 4 treatments for each compound to be tested in three replicates. Subsequently, the solvent was evaporated, and $5.0 \mathrm{~mL}$ (per well) of saline was added resulting in concentrations of 10, 100, 500, and $1000 \mu \mathrm{g} / \mathrm{mL}$ (T10, T100, T500, and T1000, each treatment being represented with numbers from 1 to 8 ). The controls used were lapachol prepared by the same procedure to provide 4 treatments with three replicates $(13,14,15$, and 16) and one treatment with saline and 4 repeats (white 17). In each test tube ten larvae of $A$. salina of the nauplii type were placed, which remained in solution for 24 hours and were finally analyzed for mortality rate to determine the toxicity of compounds by calculating the $\mathrm{LD}_{50}$ (probit method).

2.2.3. Statistical Analysis. The results presented in this study are the average of three replicates $(n=3) \pm$ standard deviation. The data obtained from the Artemia salina experiments were treated to statistical analysis using the SAEG 9.1 software and by applying the ANOVA variance, followed by Tukey's multiple comparisons test $(P<0.05)$. Graphics displaying linear regression of the stock solution of DPPH and $\mathrm{EC}_{50}$ calculations were performed using Microsoft Excel 2007 program.

\section{Results and Discussion}

3.1. Toxicity Evaluation: Artemia salina. The linear regression data (probit) indicated $\mathrm{LD}_{50}$ values for the lethal dose at $50 \%$ of the nauplii population under study showed that mammeisin at the concentrations tested was $100 \%$ lethal and therefore very toxic. Toxicity to $A$. saline shows good correlation with antitumor and insecticide activity [6], for substances when the $\mathrm{LD}_{50}$ is $<10^{3} \mu \mathrm{g} / \mathrm{mL}$. In the statistical analysis by Tukey's test $(P<0.05)$, the high toxicity of mammeisin was confirmed and evidenced by the fact that toxicity at all concentrations was equivalent to the highest concentration tested for lapachol.

3.2. Antifungal Activity. Given that mammeisin demonstrated high toxicity, we proceeded to perform an antifungal assay. For the initial dilution of mammeisin, $12.0 \mathrm{mg}$ was diluted in to $6.0 \mathrm{~mL}$ of DMSO, resulting in a concentration of $2000 \mu \mathrm{g} / \mathrm{mL}$. Next, this solution was successively diluted in to the culture medium, RPMI (Roswell Park Memorial Institute), to provide final dilutions of 512.0, 256.0, 128.0, 64.0, $32.0,16.0,8.0,4.0,2.0$, and $1.0 \mu \mathrm{g} / \mathrm{mL}$. Pure RPMI is also used as a negative control.

In the case of the antifungal standards, $5.0 \mathrm{mg}$ of either fluconazole or ketoconazole is diluted in to $5.0 \mathrm{~mL}$ of DMSO 
TABLE 1: Summary of the minimum inhibitory concentration (MIC) for mammeisin and two antifungal agents.

(a)

\begin{tabular}{lcccc}
\hline Candida & ATCC & Mammeisin (CIM) & Ketoconazole (CIM) & Fluconazole (CIM) \\
\hline C. albicans & 2209 & $512 \mu \mathrm{g} / \mathrm{mL}$ & $2 \mu \mathrm{g} / \mathrm{mL}$ & $8 \mu \mathrm{g} / \mathrm{mL}$ \\
C. tropicalis & 750 & $512 \mu \mathrm{g} / \mathrm{mL}$ & $512 \mu \mathrm{g} / \mathrm{mL}$ & - \\
C. parapsilosis & 2209 & $512 \mu \mathrm{g} / \mathrm{mL}$ & $2 \mu \mathrm{g} / \mathrm{mL}$ & $8 \mu \mathrm{g} / \mathrm{mL}$ \\
C. krusei & 6258 & $512 \mu \mathrm{g} / \mathrm{mL}$ & $2 \mu \mathrm{g} / \mathrm{mL}$ & $64 \mu \mathrm{g} / \mathrm{mL}$ \\
\hline
\end{tabular}

(b)

\begin{tabular}{|c|c|c|c|c|c|c|c|c|c|c|c|c|c|}
\hline- & 12 & 11 & 10 & 9 & 8 & 7 & 6 & 5 & 4 & 3 & 2 & 1 & - \\
\hline C. albicans & * & * & * & * & * & * & * & $*$ & $*$ & * & $*$ & $*$ & A \\
\hline C. tropicalis & $*$ & * & * & $*$ & $*$ & * & $*$ & $*$ & $*$ & $*$ & $*$ & * & B \\
\hline C. parapsilosis & * & * & $*$ & $*$ & * & * & $*$ & $*$ & $*$ & * & * & $*$ & $\mathrm{C}$ \\
\hline C. krusei & $*$ & $*$ & * & * & $*$ & * & * & $*$ & $*$ & * & $*$ & $*$ & $\mathrm{D}$ \\
\hline C. albicans & $* *$ & $* *$ & $* *$ & $* *$ & $* *$ & $* *$ & $* *$ & $* *$ & $* *$ & $* *$ & $* *$ & $* *$ & $\mathrm{E}$ \\
\hline C. tropicalis & $* *$ & $* *$ & $* *$ & $* *$ & $* *$ & $* *$ & $* *$ & $* *$ & $* *$ & $* *$ & $* *$ & $* *$ & $\mathrm{~F}$ \\
\hline C. parapsilosis & $* *$ & $* *$ & $* *$ & $* *$ & $* *$ & $* *$ & $* *$ & $* *$ & $* *$ & $* *$ & $* *$ & $* *$ & G \\
\hline C. krusei & $* *$ & $* *$ & $* *$ & $* *$ & $* *$ & $* *$ & $* *$ & $* *$ & $* *$ & $* *$ & $* *$ & $* *$ & $\mathrm{H}$ \\
\hline - & $\mathrm{C}-$ & 512 & 256 & 128 & 64 & 32 & 16 & 8 & 4 & 2 & 1 & $\mathrm{C}+$ & - \\
\hline
\end{tabular}

${ }^{*}$ Mammeisin.

**Antifungal standard (ketoconazole/fluconazole).

$\mathrm{C}+$ : positive control.

$\mathrm{C}-$ : negative control.
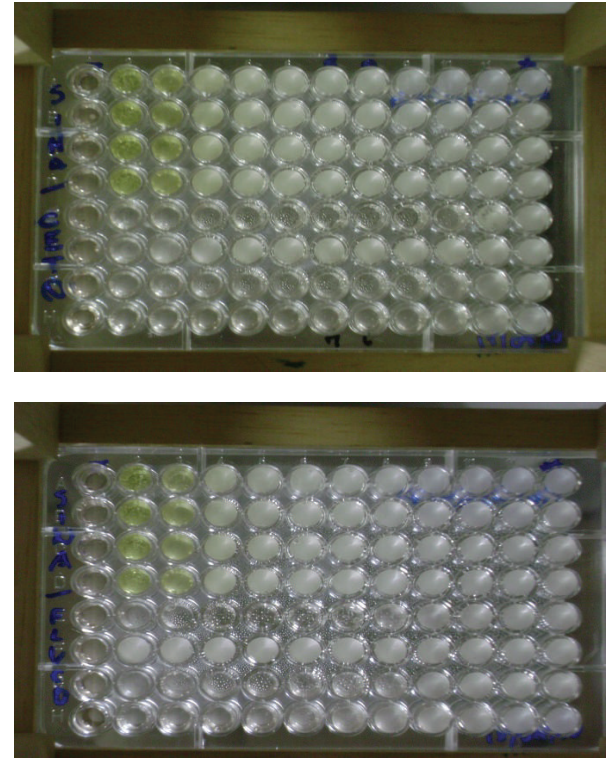

FIGURE 2: Antifungal experiment: concentrations 512-1 are given in units of $\mu \mathrm{g} / \mathrm{mL}$. Photo above corresponds to experiment with ketoconazole as positive control and photo below shows experiment carried out with fluconazole as positive control.

to give an initial solution concentration of $1000 \mu \mathrm{g} / \mathrm{mL}$, and the respective solutions are diluted in culture medium RPMI, to afford dilutions of either fluconazole or ketoconazole at the following final concentrations: $64.0 \mu \mathrm{g} / \mathrm{mL}, 32.0 \mu \mathrm{g} / \mathrm{mL}$, $16.0 \mu \mathrm{g} / \mathrm{mL}, 8.0 \mu \mathrm{g} / \mathrm{mL}, \quad 4.0 \mu \mathrm{g} / \mathrm{mL}, 2.0 \mu \mathrm{g} / \mathrm{mL}, 1.0 \mu \mathrm{g} / \mathrm{mL}$, $0.5 \mu \mathrm{g} / \mathrm{mL}, 0.25 \mu \mathrm{g} / \mathrm{mL}, 0.125 \mu \mathrm{g} / \mathrm{mL}$, and $0.0625 \mu \mathrm{g} / \mathrm{mL}$ (Figure 2).
The minimum inhibitory concentration (MIC) for mammeisin was $512 \mu \mathrm{g} / \mathrm{mL}$ for all types of Candida employed in this experiment. In comparison to the positive control, it was noted that fluconazole was not effective against the Candida tropicalis, since there was growth at all concentrations evaluated whereas mammeisin demonstrated antifungal activity against Candida tropicalis. Moreover, mammeisin was almost equally active as positive control ketoconazole for the same types of Candida and presented similar MIC. The results are outlined in Table 1.

\section{Conclusions}

To conclude, we report the antifungal activities of courmain mammeisin, against 4 different types of Candida. Mammeisin showed better MIC values for Candida tropicalis when compared to positive control fluconazole.

\section{Conflict of Interests}

The authors declare that there is no conflict of interests regarding the publication of this paper.

\section{Acknowledgments}

This work was supported by the Brazilian funding agency Fundação de Amparo à Pesquisa do Estado de Minas Gerais (FAPEMIG) under research Grant Project no. APQ-00356-13 and the Conselho Nacional de Desenvolvimento Científico e Tecnológico (CNPq) under research Grant Project no. 473461/2013-7. Authors gratefully acknowledge the generous financial support from the Universidade Federal de 
Ouro Preto, FAPEMIG, CAPES, and the CNPq for graduate research studentships and bursaries.

\section{References}

[1] J. R. S. Hoult and M. Payá, "Pharmacological and biochemical actions of simple coumarins: natural products with therapeutic potential," General Pharmacology, vol. 27, no. 4, pp. 713-722, 1996.

[2] K. Neuhaus-Carlisle, W. Vierling, and H. Wagner, "Screening of plant extracts and plant constituents for calcium-channel blocking activity," Phytomedicine, vol. 4, no. 1, pp. 67-69, 1997.

[3] A. J. Vlietinck, T. de Bruyne, S. Apers, and L. A. Pieters, "Plantderived leading compounds for chemotherapy of human immunodeficiency virus (HIV) infection," Planta Medica, vol. 64, no. 2, pp. 97-109, 1998.

[4] R. D. S. Gramacho, T. J. Nagem, T. T. de Oliveira, M. E. L. R. de Queiroz, A. A. Neves, and N. Saddi, "Phenylcoumarins from Kielmeyera elata," Phytochemistry, vol. 51, no. 4, pp. 579-581, 1999.

[5] H. Yang, P. Protiva, R. R. Gil et al., "Antioxidant and cytotoxic isoprenylated coumarins from Mammea americana," Planta Medica, vol. 71, no. 9, pp. 852-860, 2005.

[6] B. N. Meyer, N. R. Ferrigni, and J. E. Putnam, "Brine shrimp: a convenient general bioassay for active plant constituents," Planta Medica, vol. 45, no. 1, pp. 31-34, 1982. 

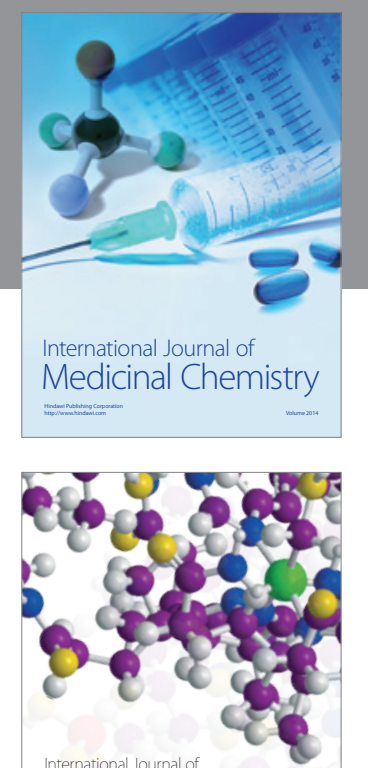

\section{Carbohydrate} Chemistry

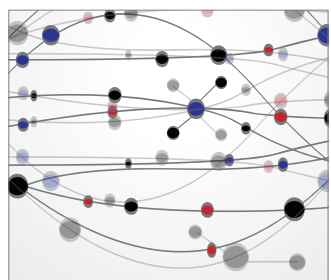

The Scientific World Journal
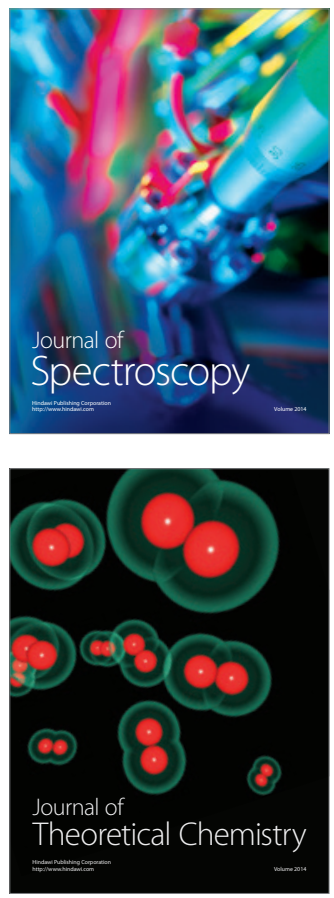
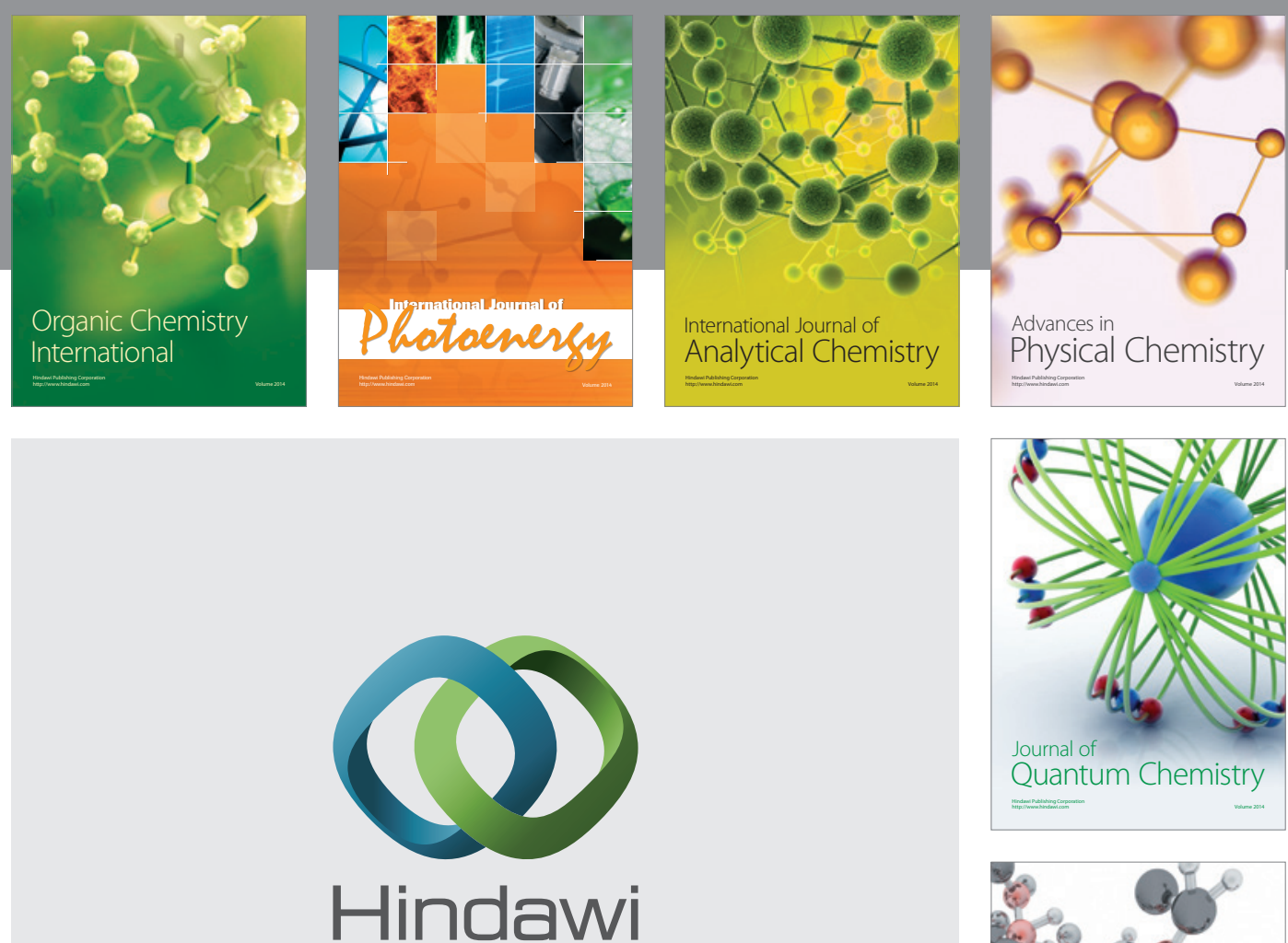

Submit your manuscripts at

http://www.hindawi.com

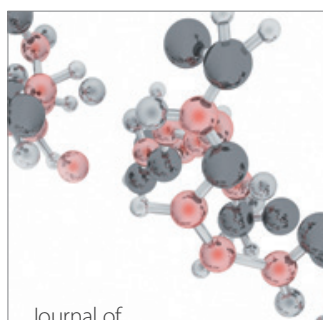

Analytical Methods

in Chemistry

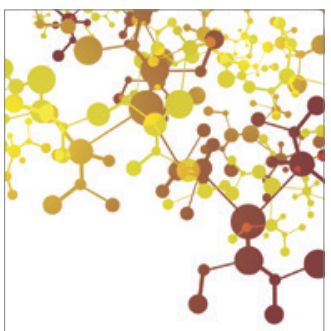

Journal of

Applied Chemistry

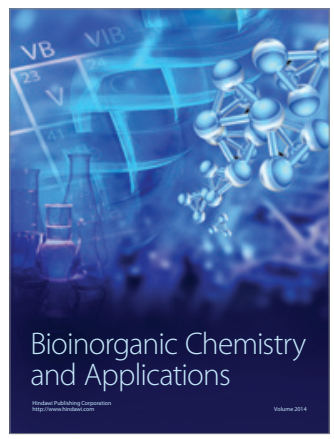

Inorganic Chemistry
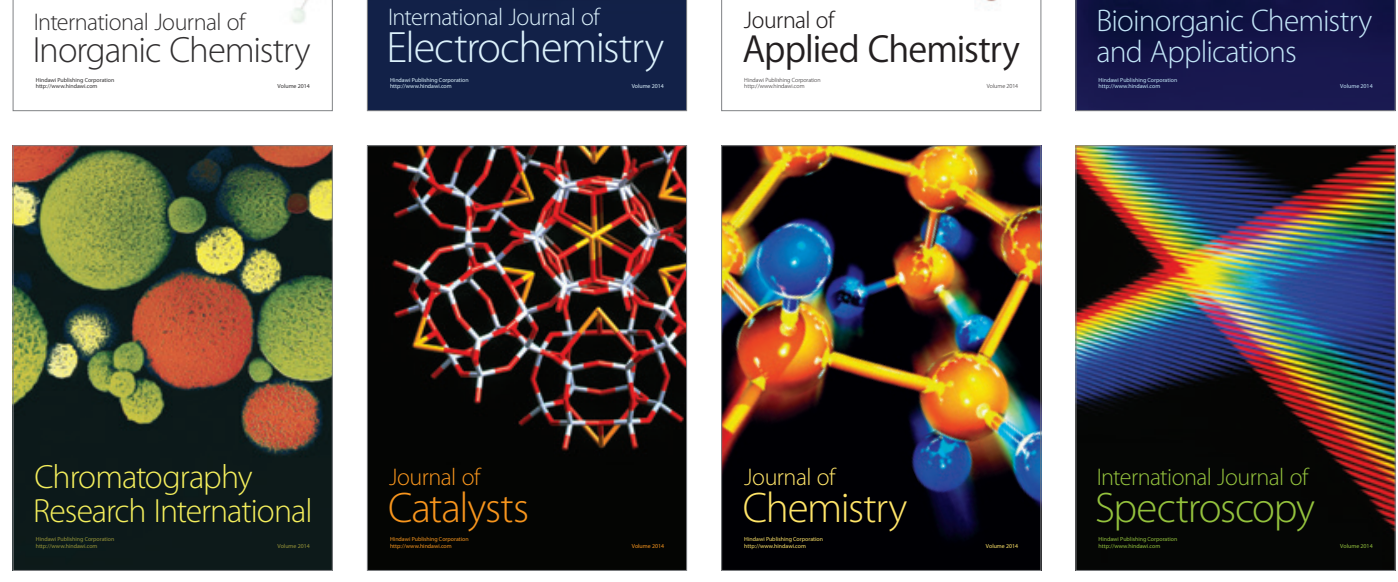